\title{
Heavy Metal Effect on Well Water and Biodiversity near Lapite Dumpsite in Ibadan, Oyo State, Nigeria.
}

\author{
${ }^{1}$ Isienyi, N. C. and ${ }^{2}$ Ipeaiyeda, A. R. \\ ${ }^{1}$ Department. of Environmental Modelling \& Management,Forestry Research Institute of Nigeria, Ibadan \\ ${ }^{2}$ Department of Chemistry, University of Ibadan, Ibadan, Nigeria.
}

\begin{abstract}
Human activities resulting from increase in population, industrialization and urbanization in Ibadan, Nigeria, have led to subsequent deposition of wastes from different parts of the city on Lapite dumpsite is no doubt a threat to the ground water and biodiversity near the area. As such this study was carried out to determine the level of heavy metal leaching from the dumpsite on well water near the dumpsite. Water sample was collected from the well located near the dumpsite for the assessment of metal leaching from the dumpsite wastes into the well water. Heavy metals such as Chromium, Cadmium, Lead, Nickel, Zinc, Copper and Manganese were determined by Atomic Absorption Spectrophotometry (AAS) after digestion with aqua regia. The results show that the heavy metals are high for $\mathrm{Pb}(0.58 \mathrm{mg} / \mathrm{L})$ and $\mathrm{Mn}(1.18 \mathrm{mg} / \mathrm{L})$, which is above the maximum acceptable limits by $\mathrm{WHO}$ and NAFDAC $(0.01 \mathrm{mg} / \mathrm{L}$ and $0.0 \mathrm{mg} / \mathrm{L} \mathrm{respectively)}$ for $\mathrm{Pb}$ and $(0.4 \mathrm{mg} / \mathrm{L}$ and $0.0 \mathrm{mg} / \mathrm{L}$ respectively) for $\mathrm{Mn}$. Because of the higher concentration and toxic nature of these heavy metals, an attempt should be directed to effective environmental management and the protection of the water quality by disposing waste effectively. Water should be treated before use and also tree planting should be encouraged in order to accumulate relatively large amounts of these elements by foliar absorption.
\end{abstract}

Keywords: Atomic Absorption Spectrophotometry, aqua regia, environmental management, and leaching

1.1 Man and Its Environment

\section{Introduction}

There has been an increasing concern about the environment in which man lives. Solid wastes, mount of rubbish, garbage and sewage are being produced everyday by our urban society. In an attempt to dispose off these materials, man has carelessly polluted the environment

[ 1 ]. Waste disposal in Nigeria has become a concern, since population has steadily increased over the last two decades as a result of population explosion and continuous growth of industries and agricultural practices. The population of Nigeria in 2003 which was estimated by the United Nations at 124,009,000 has increased to 151,319,500 in 2008 as estimated by World Bank. In 1993, 21.4 million metric tons of solid wastes were produced in the United States. [2 \& 3]. Waste materials such as municipal solid wastes (MSW) and bio-solids are high-volume wastes that could be composted instead of land filled or incinerated [4]. Nationally, composting may be an attractive waste management tool, since 30-60 $\%$ of the waste materials can be composted in an environmentally safe matter [5]. These solid wastes can as well contaminate ground water [1]. The leachate consists largely of solids, microbial organisms and in some situations chemicals and shallow wells are more dangerously polluted [1]. It has been reported by [6] that waste dumps add leachates, which may contain organic and inorganic toxic pollutants which may flow directly or percolate through permeable soil strata and pollute both surface and underground waters. "Cocktail of poison" has been reported in some part of this country Nigeria, such as in Warri in Delta state, where Warri Refining and Petrochemical Company (WRPC) waste dump site (sludge pit) and effluent discharge will find their way to the soil and river. It was equally discovered that some industrial companies bury their chemicals and hazardous chemical wastes in their backyards, thereby threatening the water quality of both surface and underground waters including the soil [7].

In the past, men thought the environment had an infinite capacity to devour their wastes without any ill effects. More recently, however, man's health and welfare are being affected by environmental pollution. These pollutants are substances present naturally in the environment but when released in significant amount by humans, become toxic. The World Health Organization (WHO) estimates that more than $20 \%$ of the world population (around 1.3 billion people) has no safe drinking water and that more than $40 \%$ of all populations lack adequate sanitation [8]. Poor water quality is still a significant problem in many parts of the world. It can often limit the use of these vital resources and in more extreme cases can harm human and other life [9]. Water can be polluted by substances that dissolve in it or by solid particles and insoluble liquid droplets that become suspended in it [1]. Moreover, groundwater contamination potential of leachate (garbage juice) from the waste matures within municipal solid waste as well as those which enter into precipitation and in groundwater for those landfills sited below the water table generate landfill leachate. These leachates contain a whole variety of conventional, non-conventional contaminants and hazardous chemicals at concentrations that renders the 
groundwater unusable for domestic water supply and many other useful purposes [10]. However, leachates from wastes at a dump site, as observed in the past study, are potential sources of contamination of both groundwater and surface water [11].

Heavy metals are referred to any metallic element that has relatively high density and is toxic or is poisonous even at low concentration [12]. "Heavy metal" is a collective term, which applies to the group of metals and metalloids with atomic density greater than $4 \mathrm{~g} / \mathrm{cm}^{3}$, or 5 times or more, greater than water. They occur as natural constituent of the earth crust, and are persistent environmental pollutants since they cannot be degraded or destroyed hence, toxic at very high concentrations to organisms and even the environment where they exist thus the great concern in their handling and release into the environment [12].

Globally, we need to appreciate the fact that our environment is a delicately balanced substance and, indeed that it is a system. Consequently, the task of protecting it is not a regional issue, neither is it a continental affair. It goes beyond local initiates, but then, we have to start from somewhere. While thinking globally we must act locally. Thus, the research becomes necessary at the present location at Lapite waste dump site in Akinyele Local Government of Ibadan, Oyo state, Nigeria, where there is little or no awareness about the dangers inherent in contaminated water and soil. It is all in an attempt to direct attention to issues of effective management of the environment and the protection of the water quality therein.

\subsection{Description of study area}

\section{Material and Method}

The research work was carried out on Lapite dumpsite, which is situated in Akinyele Local Government of Ibadan, Oyo State. The study area lies between latitude $7^{\circ} 34^{\prime} 08^{\prime \prime} \mathrm{N}$ and longitude $3^{\circ} 54^{\prime} 43^{\prime \prime} \mathrm{E}$. The well water which is in the region of the dumpsite is sited at latitude $7^{\circ} 33^{\prime} 48^{\prime \prime} \mathrm{N}$ and longitude $3^{\circ} 54^{\prime} 45^{\prime \prime} \mathrm{E}$ as shown in Fig. 1. The dumpsite is directly opposite a major road and there are vegetations at both sides of the road. There are few residential buildings, a re-habitation center, a petrol filling station and a few huts around the dumpsite. Some of the solid waste found on the site includes: scrap metals materials, garbage, paper, nylon, rubber, cartons, and cans e.t.c.

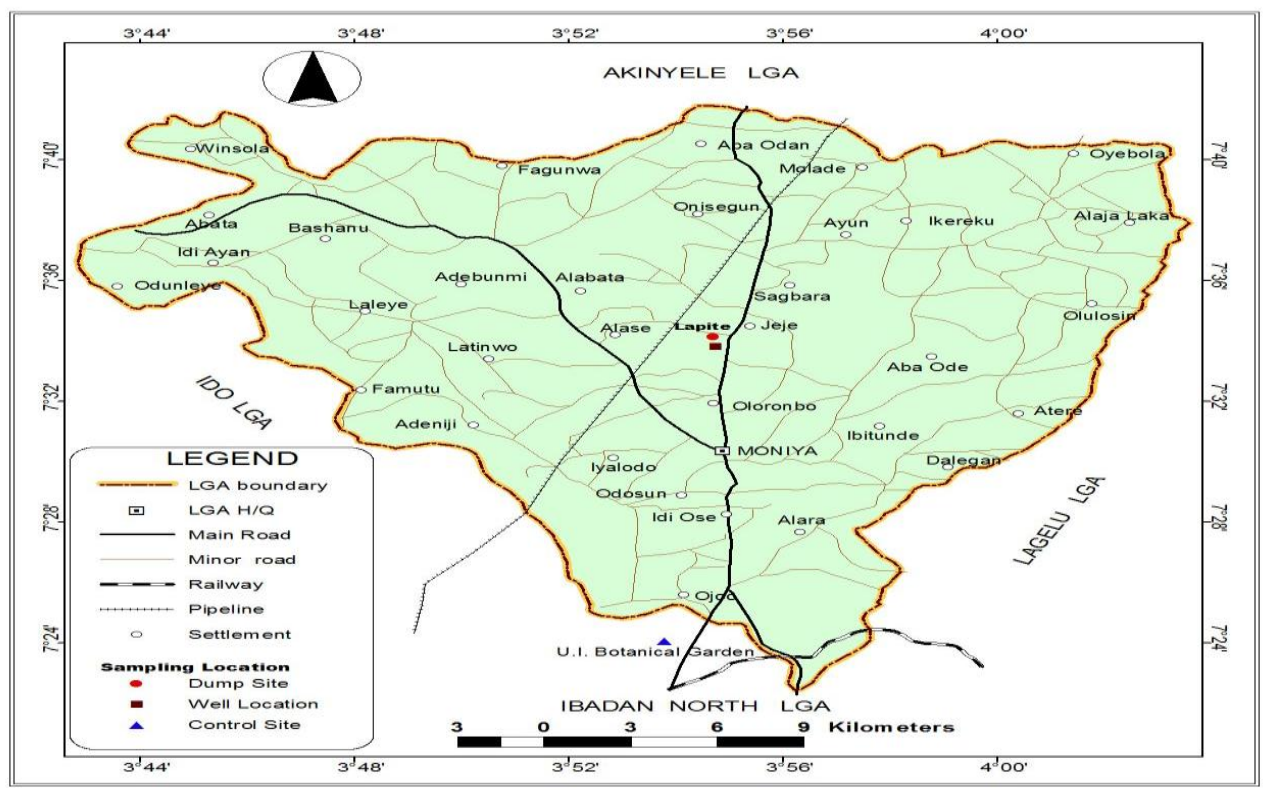

Figure 1.Map of Ibadan city showing Lapite dumpsite, location for well water and University of Ibadan botanical garden

\subsection{Collection and preservation of water sample}

water sample was collected with the aid of a drawer from the well at the petrol station close to the dumpsite and transferred into the sampling bottles and little concentrated nitric acid was added to preserve the integrity of the sample for metal analysis. The water sample was labeled LPWS. 
Heavy Metal Effect On Well Water And Biodiversity Near Lapite Dumpsite In Ibadan, Oyo State,

\subsection{Heavy metal determination in well water}

The analysis of heavy metals in the water samples involves the digestion of the water sample with aqua regia $\left(3 \mathrm{HNO}_{3}: 1 \mathrm{HCl}\right)$ and the determination of heavy metal concentration in the digest using an Atomic Absorption Spectrophotometer (AAS). The principle involves the atomization of samples by thermal sources and the absorption of a specific wavelength by the atomic source as it is excited. The radiation used is a hollow cathode lamp containing as its cathode, the same element under analysis. The quantity of the same element absorbed by the atomic vapour is proportional to the concentration of the atoms in the ground state.

\subsubsection{Instrument calibration}

The absorbance value for blank and working standard solution were measured. A plot of corrected absorbance reading versus metal concentration in the sample solution was prepared for each metal.

\subsubsection{Spectrophotometric measurement of heavy metal}

Buck Scientific (model 200A) Flame Atomic Absorption Spectrophotometer (AAS) was employed for the measurement of the absorbance of the heavy metals. The lamps of the heavy metals were operated at wavelengths specified by the manufacturer. Digestion of the water sample for heavy metal analysis was achieved with concentrated nitric acid. The sample was shaked vigorously after which $200 \mathrm{~mL}$ was measured into a clean beaker. $4 \mathrm{~mL}$ of concentrated nitric acid was then added and the resulting solution was evaporated to about $10-20 \mathrm{~mL}$. The solution was then filtered into a $25 \mathrm{~mL}$ volumetric flask. The blank sample was also subjected to similar treatment. The concentration of heavy metals in the digested samples was then determined by means of an AAS machine.

Metal concentration, $\mathrm{mg} / \mathrm{L}=\underline{\mathrm{AX} B}$

$$
\mathrm{C}
$$

Where,

A = concentration of metal (instrument reading) in the digested solution $(\mathrm{mg} / \mathrm{L})$

$\mathrm{B}=$ final volume of digested solution after making up to the mark $(25 \mathrm{~mL})$

$\mathrm{C}=$ initial volume of sample taken $(200 \mathrm{~mL})$

3.1 Variation of heavy metal in well water

\section{Results and Discussion}

Table 1: Heavy metal concentration in the well water near the Lapite dump site

\begin{tabular}{llllllll}
\hline SAMPLE & $\begin{array}{l}\mathrm{Cr} \\
(\mu \mathrm{g} / \mathrm{mL})\end{array}$ & $\mathrm{Cd}(\mu \mathrm{g} / \mathrm{mL})$ & $\mathrm{Pb}(\mu \mathrm{g} / \mathrm{mL})$ & $\mathrm{Ni}(\mu \mathrm{g} / \mathrm{mL})$ & $\mathrm{Zn}(\mu \mathrm{g} / \mathrm{mL})$ & $\mathrm{Cu}(\mu \mathrm{g} / \mathrm{mL})$ & $\begin{array}{l}\mathrm{Mn} \\
(\mu \mathrm{g} / \mathrm{mL})\end{array}$ \\
\hline LPWS & 0.08 & $<0.01$ & 0.58 & 0.02 & 0.33 & 1.19 & 1.18 \\
\hline
\end{tabular}

* LPWS is Lapite well water sample

Table 2. Maximum permissible limits of heavy metals in water as recommended by some regulatory

\begin{tabular}{lll} 
& \multicolumn{1}{c}{ bodies } & \\
\hline Heavy Metal & $\begin{array}{l}\text { Max.acceptable } \\
{[13] \mathrm{mg} / \mathrm{L}}\end{array}$ & $\begin{array}{c}\text { concentration } \\
\text { Max.acceptable concentration [14] } \\
\mathrm{mg} / \mathrm{L}\end{array}$ \\
$\mathrm{Zn}$ & 5 & 5 \\
$\mathrm{Ar}$ & 0.01 & 0 \\
$\mathrm{Mg}$ & 50 & 30 \\
$\mathrm{Ca}$ & 50 & 50 \\
$\mathrm{Cd}$ & 0.003 & 0 \\
$\mathrm{~Pb}$ & 0.01 & 0 \\
$\mathrm{Ag}$ & 0 & 0 \\
$\mathrm{Mn}$ & 0.4 & 0 \\
$\mathrm{Hn}$ & 0.001 & 0 \\
\hline
\end{tabular}

From result of heavy metal concentration $(\mu \mathrm{g} / \mathrm{mL})$ in the well water around the Lapite dump site as shown in the TABLE 1 above, such concentrations indicate the quality of the ground water at the time of sampling. Heavy metals concentrations $(\mu \mathrm{g} / \mathrm{mL})$ in the water were in the order: $\mathrm{Cd}<\mathrm{Ni}<\mathrm{Cr}<\mathrm{Zn}<\mathrm{Pb}<\mathrm{Mn}<\mathrm{Cu}$.

From TABLE 2 above, the comparism of concentrations of heavy metals in the well water to [13] and [14], Nigeria (Standard for drinking water) in order to ascertain its portability; the results show that the heavy metals are high for $\mathrm{Pb}(0.58 \mathrm{mg} / \mathrm{L})$ and $\mathrm{Mn}(1.18 \mathrm{mg} / \mathrm{L})$, which is above the maximum acceptable limits by WHO and NAFDAC $(0.01 \mathrm{mg} / \mathrm{L}$ and $0.0 \mathrm{mg} / \mathrm{L}$ respectively) for $\mathrm{Pb}$ and $(0.4 \mathrm{mg} / \mathrm{L}$ and $0.0 \mathrm{mg} / \mathrm{L}$ respectively) for $\mathrm{Mn}$, but 
other metals are within an acceptable standard. However, most of the metals were detected in the water sampled except $\mathrm{Cd}$. Their presence may be attributed to the gradual leaching or water-wash of the metals from the dumpsite soil to the well water (underground water). Even though this heavy metal concentration fell below the WHO and NAFDAC permissible limit for drinking water it seems that their persistence in the soil of dumpsite may lead to increase uptake of this heavy metals by plants. Plants can also accumulate relatively large amounts of these elements by foliar absorption. Mn was detected in a relatively high concentration compared with the standard. Solid wastes, when dissolved usually contain abundant Manganese [15].

According to [12], heavy metals occur as natural constituent of the earth crust, and are persistent environmental pollutants since they cannot be degraded or destroyed toxic at very high concentrations to organisms and even at environment where they exist. This is in line with the results obtained from this study, thus we are recommending great concern in the handling and release of waste into the environment and this should be adequately managed.

\section{Conclusion}

The outcome of the investigation carried out in this study has been very revealing in terms of the chemical and physical hazards associated with the waste from dumpsite.

The characteristic nature of the waste in the dumpsite showed that the solid waste have high proportion of biodegradable organic materials that contain polluting heavy metal. It reveals that the well water was acidic as a result leaching from the dumpsite which is in support of researchers [6 \& 11] reports. However, there is bound to be deleterious effects on human and the environment if the use of the dumpsite continues without proper management. Moreover, adequate water treatment should be encouraged in such area before consumption, awareness program or workshop should be organized in other to enhance their knowledge on implications of poor waste management and its toxic effect on human and his environment.

\section{References}

[1]. Plant, J. S., David, S., Barry, F. and Lorraine, W. 2001. Environmental geochemistry at the global scale. J. Sci. Direct. 16:12911308.

[2]. Smith, W. H. 1994b. Recycling composted organic materials in Florida. University of Florida, Gainesville Florida. pp 2-7.

[3]. Smith, W. H. 1995. Utilizing compost in land management to recycle organics. In European commission International Symposium 30 May-2 June. 1995.

[4]. Smith, W. H. 1994c. Using compost to recycle Florida's organics in agriculture. Proceedings of the Composting Council's Fifth Annual Conference. Nov. 16-18, 1994, Washington DC. pp. 44-45.

[5]. Smith, W. H. 1994a. Beneficial uses of composts in Florida. Proceedings of the second Environmentally Sound Agric. Conference, Orlando, FL. Campbell, K. L., Graham, W. D. and Del Bottcher, A. B. Eds. St. Joseph, MI: Amer. Soc. of Agr. Eng. pp. 247-253.

[6]. Benka- Coker, M. O. and Bafor, B. E. 1999. Waste Management and water pollution. Proceedings of the 25 WEDC Conference, Addis Ababa, Ethiopia. Pickford, J. A. Ed. Loughborough University, United Kingdom. Pp 12-16.

[7]. Leveque, C. 1989. The use of insecticides in the Onchocerciasis control programme and aquatic monitoring in West Africa. In P. Bourdeau, J.A Haineb, E. Kelein and C.R.

[8]. Oastridge, J. W. and Trents, R. 1999. Why is fresh water an issue for business? Background Paper. Can $176-$ oa.tr. United Nations $-\mathrm{CDS}, \mathrm{p} 9$.

[9]. Forum, U. and Entwicklung, C. 2001. Policy paper for the Bonn International conference on freshwater. World Water Conference, 4th Dec., Bonn.

[10]. Chilton, P. J. and Foster, S. S. D. 1995. Hydrogeological and characterization and water supply potentials of basement aquifers in tropical Africa. Hydrogeology Journal 3: 36-49.

[11]. Odukoya, O. V., Arowolo, T. and Bamgbose, O. 2002. Effects of solid waste landfill on underground and surface water quality at Ring Road, Ibadan, Nigeria. Global Journal of Environmental Science 1.1: 43-52.

[12]. Lenntech water treatment and air pollution 2004. Water Treatment, Published by Lenntech, Rotterdamseweg. Netherlands. Rotterdamseweg. Retrived Dec. 14 ${ }^{\text {th }}, 2009$. From www. Excelwater.com/thp/filters/water -purification.

[13]. World Health Organization (WHO). 2006 Guidelines for drinking water quality, Vol. 1,3 $3^{\text {rd }}$ ed. Retreived from www.who.int/watersanitation-health/GDWQ 3rev/en/index.htmi on $5^{\text {th }}$ June 2010.

[14]. The National Agency for Food Drug Administration and Control

[15]. Hughes, J.L. 2004. Evaluation of groundwater Degradation Result from Waste Disposal to Alluvium Near Barstow, California. U.S. Geological survey professional Paper 878 . 